\title{
Development Trend of Sino-Japanese Economic and Trade Relations
}

\author{
Juan $\mathrm{Du}^{1}$, Jing Xiao ${ }^{2} \&$ Zhijun Sheng ${ }^{2}$ \\ ${ }^{1}$ Office of academic affairs, Changchun University of Science \& Technology, Changchun, 130022, China \\ ${ }^{2}$ School of Economics and Management, Changchun University of Science, \&Technology, Changchun 130022, \\ China \\ Correspondence: Zhijun Sheng, School of Economics and Management, Changchun University of Science \& \\ Technology, Changchun 130022, China. Tel: 86-135-0445-7191. E-mail: shengzhijun412@126.com
}

Received: June 1, 2014

doi:10.5430/bmr.v3n2p120
Accepted: June 16, 2014

Online Published: June 19, 2014

URL: http://dx.doi.org/10.5430/bmr.v3n2p120

\begin{abstract}
The Diaoyu Islands dispute has caused serious influence on the Sino Japanese economic relations, and bilateral investment and trade has been hindered. Based on the Diaoyu Islands Dispute, this paper expounds current situation of the Sino Japanese economic and trade relations, analyzes complementarity and interdependence of economy and trade between the two countries, and makes a prospect for the future development of bilateral economic and trade cooperation.
\end{abstract}

Keywords: Diaoyu Islands Dispute, Trade relations, Economic and trade cooperation

\section{Introduction}

Since 2008, affected by the worsening of the international financial crisis and other economic conditions, the Sino-Japanese economic and trade cooperation has emerged decline. Coupled with the impact of the Diaoyu Islands dispute, Sino-Japanese economic and trade cooperation has been facing an unprecedented situation that people do not want to see. Sino-Japanese relations change from the former "politically cold and economically hot" pattern, into the current "cold politics and economically cold" pattern. (Zhang, 2013) China and Japan should find the right time to repair their political relations and pull economy to normal track, which conforms to the fundamental interests of both countries.

\subsection{Status of the Sino-Japanese economic and trade}

1.1.1 The decline of Sino-Japanese economic and trade

Since September 2012, the Japanese government's "Island purchase" behavior resulted in the Sino-Japanese tensions (Ran, 2013), which overshadowed the Sino-Japanese economic and trade relations. Taking Japan's auto industry for example, in September 2012, the Japanese auto exports to China decreased by 44.5 percent, auto parts exports to China fell 17.5 percent. The entire third quarter of 2012, Japan's automobile exports to China fell by 70 percent, auto parts exports fell by about 40\%. In addition, the Japanese tourism industry was sluggish. In September 2012 to mid-October, due to the reduced number of Chinese tourists to Japan, 122 flights have been temporarily suspended in Japan weekly; it means grounded proportion reached $16 \%$. Of course, China's economy will not be "immune." According to China's auto industry development policy, in the China and Japan joint production enterprises, the Chinese share should be more than $50 \%$. Therefore, the loss of Japanese auto companies has directly led to the loss of China. In addition, the Japanese auto industry already has a matching upstream and downstream industry chain in China, the Japanese auto industry sales decline resulted in the loss of supporting Chinese enterprises. Deterioration of Sino-Japanese economic and trade relations continued until September 2013. According to Chinese Customs, it shows: first half of the year 2013, Sino-Japanese trade amounted to US\$ 147.27 billion, down 10.8 percent, Japan's total exports to China was CN¥61.43 billion, down $16.7 \%$, reaching the lowest record in four years. In addition, Japan shifted investment focus to Southeast Asia, reducing investment in China. In the first half of the year 2013, Japan's direct investment fell 18 percent, only 470.1 billion yen, while direct investment in ASEAN was about twice that of China, to reach 1 trillion yen, which is four times that of last year.

\subsubsection{The recovery of Sino-Japanese economy and trade relations}

In September 2013, the Sino-Japanese economic and trade relations were getting warmer, Japan's exports to China grew by $11.4 \%$; imports from China grew by $30.9 \%$. In terms of tourism, the Japan National Tourist Office's 
investigation shows that the proportion of Chinese self-service tourists increased from 23 per cent in July to September 2012 to 43\% in October to December 2013. As to Automotive industry, in October 2013, sales of Honda cars in China reached 75,000 vehicles, three times that of last year in October. Toyota Group also said that their October sales in China grew 80.6 percent to US\$ 82,400. Although in 2013 Japan imported electronic products from China declined by 3 percent over the same period, to US\$37.83 billion, it still showed a modest growth trend of electrical and other audio-visual equipment. $(\mathrm{Xu}, 2010)$ The result benefited from the Sino-Japanese economic and trade relations and efforts rehabilitated. In November 2013, hundreds of Japanese business leaders had a conference in Beijing to rehabilitated deteriorating economic and trade relations. In addition, the Delegation of Japanese companies, represented by Toyota Motor Group visited China in November 2013. They met with Chinese leaders and held meetings with Chinese trade, investment and environmental protection departments. They put territorial disputes between China and Japan aside, discussed tax relief with the ROK FTA, and reached a consensus on 15 fields for the next round of negotiations. These measures to some extent acted as buffer against the tense Sino-Japanese trade relations.

\section{The complimentarily of Sino-Japanese economic and trade}

After years of development, economic and trade relations between China and Japan expanded from mere merchandise trade to comprehensive economic cooperation including trade in goods, technology trade, mutual investment, funds cooperation between the Governments (Zhao, 2013), the importance of trade and economic cooperation between the two countries is growing.

\subsection{The importance of Japan to China economy and trade}

Data released by the Ministry of Commerce shows that in 2013, there was a deficit of China in bilateral trade with Japan, which indicates that China has a strong "stealth dependence" on Japanese. First, by analyzing the trade structure between China and Japan, it can be found that, China's importing from Japan are mainly semiconductors, electronic products, precision machinery, which offered basic materials for China as "world factory". China imports raw materials and production equipment from Japan, assembles in the country, and then exports to foreign countries. Lack of supply of raw materials from Japan, China and the United States and Europe would no longer be a normal trade. In addition, Japan's exports to China are intermediate products and production equipment with high added value and hard to replace; China mainly exports to Japan are mechanical and electrical products, textiles, toys and furniture, which are labor-intensive and low value-added, but also faces competition in Southeast Asian countries. Secondly, in terms of foreign investment, China is heavily dependent on Japanese investment. In 2012, Japan's investment in China reached US\$ 7.38 billion. Japan's investment increased year by year, so many well-known Japanese companies such as Canon, Panasonic have completed the "localization" process. These Japanese companies offer nearly 10 million jobs in China.

\subsection{Importance of China's economy and trade to Japan}

First, China is the most important overseas market to Japan's auto industry, Japanese car sales has been a leading position among foreign car brands in China. Second, Japan has an energy shortage, so Japan imports Chinese energy to maintain giant domestic energy consumption. In addition, rare metals, which are important to the rapid development of the Japanese high-end manufacturing, high-tech manufacturing and supporting the development, are imported from China. Finally, Japan's tourism industry relies heavily on the Chinese market. China and Japan are near to each other, coupled with China's large consumer groups, which together constitute the Japanese tourism industry's dependence on China. According to Japanese authorities, Chinese tourist's consumption in Japan is 160,000 yen per capita, which is twice that of other countries' tourists in the world.

\section{Prospects on the Sino-Japanese economic and trade relations}

After the financial crisis era, the economic and trade structure meets across strategic adjustment and structural upgrade. CJK FTA is in line with the trend of future development in Asia. In order to maintain the current pattern of important bilateral trade, the two sides should be a think about the future rationally. (Zhang, 2013)

\subsection{Japan and South Korea trade and economic cooperation}

In addition to great geopolitical outside among these three countries, the three have complementary advantages. If Japan and South Korea established a free trade zone, eliminated tariffs and other trade restrictions, it would undoubtedly promote trade among three countries to achieve common prosperity. Manufacturers and trade zone may thus reduce production costs, expand market area, and enjoy more preferential treatment. 


\subsection{Green environmental protection cooperation}

China and Japan should also cooperate in the field of environmental protection. Currently, low-carbon economy and green environment is advocated all over the world. In 2013 nationwide fog and haze appear, which shows the defects and shortcomings still exist in China in terms of environmental protection. Japan has obvious advantages in research and development of hybrid and other environmentally friendly vehicles, not only that, but also master the Japanese heavy industry energy saving technology. Therefore, the strengthening of Sino-Japanese cooperation in environmental protection can ease to some extent and promote economic and trade relations between China and Japan.

\subsection{Exchanges and cooperation of the service trade}

Sino-Japanese exchanges on services trade can expand and enrich the connotation of the Sino-Japanese economic and trade cooperation. For example, the Japanese may explore the problem of aging together. Aging population is the two countries' common problem, while Japan has extensive experience in elderly services, for example, aspects of aged care facilities and health care equipment. In the financial services sector, China can learn from Japan cultivate debt markets, and expand the scale of the cross-bonds and other initiatives to maintain a stable and secure financial markets reserve assets, which has positive significance for the huge foreign exchange reserves held by China and Japan.

\subsection{Modern Agricultural Logistics Cooperation}

Chinese and Japanese may expand exchanges and cooperation on food security and agricultural trade. China and Japan also face the problem of expanding domestic demand and improving people's living. The development of green agriculture and strengthening agricultural products circulation system are important measures to achieve these goals. Two countries could work together to seek measures to ensure food security, agriculture and logistics to promote bilateral cooperation.

\section{Conclusions}

In summary, there is complementarity of trade between China and Japan, they are interdependent and mutual restrained. Sino-Japanese political conflict may not end in a short time, but the economic and trade relations between the two countries should take active measures to be rehabilitated and maintenance, and should actively seek opportunities to promote economic and trade cooperation to achieve mutual benefit and common prosperity.

\section{References}

Ran, Dongfan \& Huang, Rui. (2013). Times Finance: Brief Discussion on the Impact of Diaoyu Islands Event on Sino-Japanese economy.

Xu, Xiude \& Li, Chen. (2010). Japanese Research: Complementarily Interdependence and Sensibility of Sino-Japanese Trade Cooperation.

Zhang, Jifeng. (2013). Asia \& Africa Review: Sino-Japanese Economic relations under the impact of Diaoyu Islands dispute.

Zhang, Kuiyuan \& He, Cangsong. (2013). Journal of Guangxi University of Finance and Economics: Status of the Japanese Economy and Outlook of Japanese Economic and Trade Relations.

Zhao, Xuwen. (2013). Northern Economy and Trade: Brief Analysis on Historical Summary and Countermeasures of Sino-Japanese Trade Relations. 